DOI:

\title{
APVĒRSTĀ MĀCĪŠANĀS DAŽĀDU MĀCĪBU MĒRĶU SASNIEGŠANAI FIZIKAS UN MATEMĀTIKAS STUNDĀS
}

\author{
FLIPPED LEARNING AS A WAY TO ACHIEVE \\ VARIOUS LEARNING OBJECTIVES IN PHYSICS \\ AND MATHEMATICS LESSONS
}

\author{
Anda Priedīte \\ Latvijas Universitāte \\ priedite.anda@gmail.com
}

\begin{abstract}
ANOTĀCIJA
Viena no mācību darba organizācijas formām, ko mūsdienās aktīvi izmanto daudzās valstīs, ir t. s. apvērstā mācīšanās (flipped learning), kurā nozīmīga loma ir skolēnu patstāvīgajam darbam pirms stundas un informācijas tehnoloǵijas lietojumam (tiek izmantoti video materiāli, pašpārbaudes testi, tiešsaistes diskusijas u. c.). Pētījuma mērkis ir izzināt, kāda veida mācību mērḳu sasniegšanai apvērstā mācišanās efektīvi izmantojama fizikas un matemātikas stundās. Lai to sasniegtu, tika izstrādāti un aprobēti fizikas un matemātikas stundu plāni vidusskolā, anketēti skolēni un analizētas skolotāju piezīmes. Pētījumā tika secināts, ka apvērstā mācišanās ir efektīvi izmantojama, lai aktualizētu gan fizikā un matemātikā, gan arī citos mācību priekšmetos gūtās zināšanas un prasmes un îstenotu integrēto mācību stundu, kā arī lai attīstîtu skolēnu pētnieciskās darbības prasmes un veicinātu motivāciju mācīties. Raksta noslēgumā apkopoti ieteikumi apvērstās mācīšanās izmantošanai.
\end{abstract}

Atslēgvārdi: apvērstā mācīšanās, mācīšanās organizācijas formas, mācību stundu plānošana.

Key words: flipped learning, organization of the learning process, lesson planning.

\section{Ievads}

Matemātikas centralizēto eksāmenu rezultāti rāda, ka liela dạ̣a vidusskolas beidzēju matemātiskos pārveidojumus tipveida matemātiskajos 
uzdevumos veic mehāniski, neizprotot darbību būtību (Čakāne et al. 2016: 70). Ir maz tādu skolēnu (aptuveni 5\%), kuri spēj izpildīt augstākās grūtības pakāpes uzdevumus (4. līmen,a uzdevumus pēc SOLO taksonomijas). Arī PISA (Programme for International Student Assesement) pētījuma rezultāti liecina, ka tikai 3,8\% skolēnu matemātiskā kompetence atbilst 5. vai 6. līmenim (sešu līmeņu skalā). Šie rezultāti ir 2 reizes zemāki par vidējiem rādītājiem (7,8\%) pētījuma valstīs (Geske et al. 2016: 73). Lai uzlabotu situāciju, tipveida uzdevumu daudzuma palielināšana mācību procesā nav efektīva (Čakāne et al. 2016: 70). Mācību saturā jāiekḷauj uzdevumi, kas palīdz skolēniem labāk izprast veicamās darbības. Diemžēl pētījumā, kura laikā tika vērotas un analizētas matemātikas mācību stundas Latvijā (France et al. 2015: 50), tikai 29\% vēroto stundu tika konstatēta skolēnu augsta līmen,a kognitīva darbība, tātad pārsvarā mācību process ir reproduktīvs. Tāpat tika secināts, ka mācības lielākoties ir frontālas, - tajās dominē skolotāja stāstījums, uzdotā atprasīšana un tipveida uzdevumu risināšana, bet informācijas tehnoloğijas (IT) lietojums nav jēgpilns. Tas nozīmē, ka nepieciešami uzlabojumi mācību procesā, jo tam mūsdienās jābūt progresīvam, skolēncentrētam, tādam, kurā skolēns ir aktīvs procesa dalībnieks, bet skolotājs ir procesa vadītājs.

Pedagoǵiskajā literatūrā tiek piedāvātas dažādas mācību organizācijas formas un mācību stundu plānošanas pieejas. Viena no tām ir t. s. apvērstā mācīšanās (flipped learning). Tā ir mācību organizācijas forma, kas tiek izmantota, lai sekmētu skolēnu patstāvīgu gatavošanos mācību stundām. Lai arī doma, ka skolēni labāk apgūst mācību saturu, ja iepriekš ir patstāvīgi gatavojušies stundai, nav jauna, mūsdienās tā ir kḷuvusi īpaši populāra tāpēc, ka internets un viedierīces skolēniem ir kḷuvušas daudz pieejamākas (Hao, Lee 2016: 255). Līdz ar to gatavošanās mācību stundām var notikt interaktīvi. Skolēni pirms stundas var ne tikai patstāvīgi apgūt mācību saturu, bet arī san,emt atgriezenisko saiti par apgūto.

Tā kā, plānojot mācību stundu, vispirms precīzi jānosaka tajā sasniedzamais rezultāts, tad šì raksta mērḳis ir izpētīt un aprakstīt, kāda veida mācību mērḳu sasniegšanai mūsdienās efektīvi izmantojama apvērstā mācīšanās kā viena no mācību organizācijas formām. Lai mērḳi sasniegtu, tika analizēti dati, kas iegūti maǵistra darba pētījumā, kura laikā tika izstrādāti un aprobēti stundu plāni fizikā un matemātikā vidusskolas klasēs (Priedīte 2017).

\section{Apvērstās mācīšanās teorētiskais pamatojums}

Izmantojot apvērsto mācīšanos, iespējams realizēt uz skolēnu virzìtu mācību procesu. Skolēni pirms stundas sagatavojas darbam, kas paredzēts konkrētajā mācību stundā. Tādējādi stundas laiks var tikt pilnvērtīgi izmantots, lai diskutētu, risinātu problēmsituācijas, sadarbotos un padzilịnātu 
iegūto zināšanu izpratni. Šādu mācību organizācijas formu tās popularizētāji Džonatans Bergmanis un Ārons Samss (Bergmann, Sams 2012: 13) sauc par apvērsto mācišanos, jo tajā it kā tiek mainīts vietām klases darbs ar mājas darbu. Tradicionāli skolotājs stundas laikā sniedz jauno informāciju, bet mājas darbā skolēni papildus nostiprina iegūtās zināšanas. Savukārt šajā mācību organizācijas formā skolēns pirms stundas apgūst jauno informāciju (visbiežāk noskatoties ìsu video lekciju), bet stundā strādā ar jauno informāciju.

Angḷu valodā pedagoğiskajā literatūrā tiek izmantoti divi apzīmējumi flipped classroom un flipped learning (Toivola, Silfverberg 2014: 2), bet to lietojumā nav stingra nošķīuma. Apzìmējums flipped classroom parasti tiek attiecināts uz tehniskām pārmaiņām mācību procesā, bet flipped learning uz pārmaiṇām gan mācību procesa ogranizācijas formā, gan arī skolotāju un skolēnu pieņēmumos par mācǐšanos (Toivola, Silfverberg 2014: 3). Šajā rakstā tiek lietots apzīmējums apvērstā mācišanās, attiecinot to uz pārmaiṇām gan mācību stundas organizācijā, gan pašā mācību procesā, kuru rezultātā tiek veicināta skolēnu autonomija, attīstas sadarbības prasmes un skolotājs var diferencēt darbu stundā atbilstoši skolēnu vajadzībām.

Izmantojot šo mācību organizācijas formu, skolēnam pirms stundas tiek nodrošināta pieeja skolotāja veidotajiem vai atlasītajiem materiāliem, piemēram, mācību materiālu prezentācijām, informatīvajiem tekstiem, videoierakstiem. Parasti šie materiāli skolēniem ir pieejami interneta vidē. Skolēni patstāvīgi, izmantojot piedāvātos resursus, apgūst mācību tematu paša izvēlētā vietā, laikā un tempā (Bergmann 2013). Strādājot ar šiem materiāliem, skolēni ārpus klases apgūst zināšanas un formulē jautājumus, kas stundā jāpārrunā. Mācību stundas laiks tiek veltīts izpratnes veidošanai un prasmju attīstišanai (Creative Classroom Lab 2012: 7). Apvērsto mācišanos iespējams izmantot dažādos mācību priekšmetos, it ìpaši tajos, kur nozīmīga loma ir priekšzināšanām, lai stundās varētu vairāk laika veltìt augstākas grūtības pakāpes uzdevumiem, kuru veikšanā skolotāja atbalsts un atgriezeniskā saite ir nepieciešama vairāk nekā zināšanu apguvē.

Šādi organizējot mācību procesu, mācǐšanās ir elastīga - skolēni var apgūt pamatjautājumus par tematu arī tad, ja nav bijuši stundā, vai arī apgūt saturu, kas būs nepieciešams nākamajās stundās, tātad - mācīties vairāk (Bergmann, Sams 2012: 22). Skolēni mācās plānot savu laiku, attīsta pašregulācijas prasmes. Atsakoties no frontāla darba stundā, laiku var izmantot, lai darbotos praktiski, izmantojot iegūtās zināšanas, attīstītu prasmes, sadarbotos un diskutētu. Skolotājam ir iespēja vairāk mijiedarboties ar skolēniem, strādāt individuāli vai ar skolēnu grupām. Efektīvi organizēts mācību process palīdz novērst klasvadības problēmas (Bergamnn 2013). Arī skolēni pozitīvi vērtē apvērsto mācišanos un raksturo to kā efektīvu un noderīgu (Bergmann, Sams 2012: 20; Mok 2014: 10). Kā ieguvumu skolēni min to, 
ka iespēja sagatavoties darbam stundā paaugstina savu zināšanu un prasmju pašnovērtējumu (Priedīte 2017: 37). Pētījumi rāda (Bhagat, Chang, Chang 2016: 138; Priedīte 2017: 36), ka iespēja mācīties paša noteiktā tempā, piemēram, apturēt video, noskatīties to atkārtoti, uzdot neskaidros jautājumus, ir īpaši svarīga skolēniem ar zemākiem mācību sasniegumiem. Viņi labprāt skatās video un pilda uzdevumus interneta vidē, jo tā ir saprotama un ērti lietojama (Priedīte 2017: 39).

Tomēr šādai mācību organizācijas formai ir arī trūkumi. Skolēniem var būt nepietiekamas prasmes mācīties patstāvīgi, iespējams, būs nepieciešams attīstīt viṇu pašregulācijas spējas (Lai, Hwang 2016: 130). Skolēni ir jāmāca, kā gatavoties stundām, kā izmantot pieejamos materiālus. Lai arī interneta un viedierīču pieejamība ir minētas kā priekšrocības, tomēr jāṇem vērā, ka ne visiem skolēniem ir šādas iespējas. Skolotājam ir jāpārliecinās, ka skolēni var piekḷūt materiāliem ārpus klases, un jāpiedāvā risinājums, ja šādas iespējas nav, piemēram, piekḷuve datoram skolā vai bibliotēkā (Bergmann, Sams 2012: 96). Izmantojot apvērsto mācīšanos, ir svarīgi informēt vecākus par to, ka skolēni lietos informācijas tehniskās ierīces ārpus klases, un saņemt vecāku piekrišanu un atbalstu (Creative Classroom Lab 2012: 6). Tāpat jāṇem vērā skolēnu kopējais mājas darbu apjoms, lai tas būtu samērīgs un pie ekrānierīcēm pavadītais mācību laiks nebūtu pārāk ilgs. Pirms uzsākt šādi organizēt mācību darbu, skolotājam ir jāiegulda daudz laika un resursu, lai sameklētu un izveidotu atbilstošus materiālus skolēnu patstāvīgajam darbam. Tāpat, ņemot vērā konkrēto skolēnu mācīšanās vajadzības, skolotājam, iespējams, būs nepieciešams sagatavot diferencētus mācību materiālus ne tikai darbam stundās, bet arī skolēnu patstāvīgajam darbam pirms stundas.

\section{Pētījuma norise un metodes}

Rakstā izmantotie dati iegūti pētījumā, kas tika veikts laika posmā no 2017. gada janvāra līdz aprīlim Ventspils Valsts 1. ǵimnāzijā un kurā tika iesaistīti piecdesmit astoņi 10. un 11. klases skolēni un divi skolotāji (Priedīte 2017). Pētījuma mērksis bija uzlabot mācību procesu fizikas un matemātikas stundās, lai radītu skolēniem iespēju uzņemties lielāku atbildību par savu mācīšanos un padarītu mācību stundu efektīvāku. Pētījuma laikā tika izstrādāti, aprobēti un uzlaboti stundu plāni fizikā un matemātikā. Katras stundas beigās skolēniem tika lūgts sniegt īsu novērtējumu, kā viņi gatavojušies stundai, kas sagādājis grūtības un kāds ir sava darba vērtējums atbilstoši stundas sasniedzamajiem rezultātiem. Skolotāji pēc mācību stundas rakstīja dienasgrāmatu par stundas norisi, sasniegtajiem rezultātiem un ieteikumiem stundas plāna īstenošanai. Šie dati pētījumā tika analizēti, lai izdarītu secinājumus par to, kādu mērḳu sasniegšanai apvērstā 
mācǐšanās ir efektīvi izmantojama, un izstrādātu ieteikumus šādas mācību organizācijas formas īstenošanai fizikas un matemātikas stundās vidusskolā.

Plānojot stundas, tika noteikts, kāds rezultāts skolēniem jāsasniedz, gatavojoties stundai, un kāds - stundā. Gatavojoties stundai, skolēniem bija jānoskatās 5-10 min. garš video materiāls. Tas tika veidots atbilstoši stundas trīs fāžu modelim. Katra video sākumā ieplānota ierosināšanas fāze, kam seko apjēgšanas fāze, kurā ir ieklauts skolotāja skaidrojums un demonstrēts piemērs. Bet lietošanas fāzē skolēniem tiek piedāvāts pašpārbaudes uzdevums (sk. video piemēru šeit: https://youtu.be/w4V0Nb7k2cU). Bieži vien video materiālam tika piedāvāta alternatīva, piemēram, teksts mācību grāmatā. Pārsvarā tika izmantoti pētījuma autores veidoti video materiāli, bet reizēm - arī citu autoru materiāli, piemēram, tie, kas pieejami www. fizmix.lv, www.macibuvideo.lv, kā arī video angḷu valodā, piemēram, www.khanacademy.org un www.ted.com. Pēc video noskatīšanās, lai gan skolēni, gan skolotājs varētu pārliecināties par izvirzitā mērḳa sasniegšanu, skolēni izpildīja testu un saṇēma tūlìtēju atgriezenisko saiti par apgūto. Testa pildišanai bija aț̣auti divi mēǵinājumi. Izpildot testu pirmo reizi, skolēns redz, kuriem jautājumiem jāpievērš papildu uzmanība, un var, piemēram, noskatīties video vēl vienu reizi vai atrast informāciju mācību grāmatā. Skolēniem bija arī jāuzraksta jautājumi, kas radušies, skatoties video vai pildot testu. Atbildes uz tiem sniedza klasesbiedri un / vai skolotājs. Visi video materiāli, testi un tiešsaistes forumi, kur rakstìt jautājumus, skolēniem bija pieejami www.eduspace.lv vidē. Lai sagatavotos mācību stundai, skolēniem bija nepieciešamas aptuveni 15-20 minūtes. Pētijuma noslēgumā tika noskaidrots skolēnu viedoklis par ieguldīto laiku, gatavojoties stundām. Visi skolēni, kas piedalījās fokusgrupas diskusijā, atzina, ka viniiem mājas darba apjoms škita atbilstošs un ka viṇi gribētu tā mācīties arī turpmāk (Priedīte 2017: 37). Jāpiebilst, ka pirms pētījuma skolēniem fizikas stundās netika regulāri uzdoti mājas darbi.

\section{Apvērstās mācīšanās izmantošanas mērḳi}

Izanalizējot pētijumā (Priedīte 2017) iegūtos rezultātus, tika secināts, ka apvērstā mācīšanās kā mācību organizācijas forma ir piemērota dažādu mācību mērḳu sasniegšanai. Rakstā aplūkoti tikai tie mērķi, kuru sasniegšanai, pēc autores domām, apvērstā mācīšanās ir īpaši veiksmīgi izmantojama.

\section{Iepriekš apgūta mācību satura aktualizēšana}

Viena no problēmām, ar ko skolotāji saskaras mācību procesā, ir skolēnu priekšzināšanu atškiriīgais līmenis (Priedīte 2017: 50). Mācību laikā skolēniem bieži jāizmanto iepriekš apgūtās zināšanas un prasmes. Piemēram, 
8. klasē matemātikā tematā „Ievads statistikā” skolēni apgūst jēdzienus un prasmi aprēḳināt vidējo aritmētisko, modu, mediānu, amplitūdu, relatīvo biežumu, bet 11. klasē tematā „Statistikas elementi” šie jēdzieni skolēniem ir brīvi jālieto. Šìs iepriekš apgūtās zināšanas un prasmes ir jāaktualizē. Efektīvs veids, kā to darīt, ir izmantot apvērsto mācīšanos. Pirms stundas skolēni, izmantojot skolotāja sagatavotos materiālus, patstāvīgi atkārto konkrētajai stundai nepieciešamās zināšanas un prasmes, tādējādi samazinās atšksirība starp dažādu skolēnu priekšzināšanu līmeni stundas sākumā. Tā kā skolēni patstāvīgi aktualizē stundas tematu, tad, atnākot uz stundu, viṇi zina, kas stundā būs jādara, un ir ātrāk gatavi darbam. Pētījumā (Priedīte 2017: 35) tika salīdzināti apvērstās mācī̌sanās stundu plāni ar attiecīgajiem iepriekšējā mācību gada stundu plāniem un tika secināts, ka šādi katrā stundā var saīsināt ierosināšanas fāzi par 5-10 minūtēm. Mācību gadā fizikā tas veido vairāk nekā 10 mācību stundas. Šo papildus iegūto laiku var izmantot, lai stundā mērḳtiecīgi strādātu ar jauno mācību saturu, pildītu augstāka izziņas darbības līmeņa uzdevumus, izvērtētu sasniegto un pārrunātu dažādu mācību formu un mācīšanās pan̦ēmienu izmantošanas iespējas. Par to, ka apvērstās mācīšanās forma palīdz skolēniem sagatavoties darbam stundā, liecina arī skolēnu atsauksmes, piemēram, „palīdzēja atcerēties to, kas mācīts senāk, un vēl vairāk saprast, pirms stundas apskatīt, ko nesapratu.”, „ar video palīdzību es varēju labi sagatavoties stundai, jo zināju, par ko mēs mācīsimies, un atkārtoju, ko par šo tēmu jau zinu". Pētījumā skolēniem tika jautāts, vai viṇi piekrīt apgalvojumam, ka pirms stundas piedāvātā materiāla saturs ir iepriekš apgūtā atkārtojums. Skolēnu atbildes liecināja, ka skolēni ne vienmēr piekrīt šim apgalvojumam, piemēram, „Galīgi nē. Skolotājs varbūt to atceras [..]. Bet es, piemēram, pēc trīs mēnešiem jau vairs neatceros, ko mēs tur esam darījuši" (Priedīte 2017: 38).

\section{Patstāvīga sagatavošanās integrētai mācību stundai}

Arī otrs apvērstās mācīšanās izmantošanas mērḳis ir saistīts ar apgūto zināšanu un prasmju aktualizāciju. Veidojot integrēto mācību stundu, kurā izmantots vairāku mācību priekšmetu saturs, skolotāji var saskarties ar situāciju, kurā skolēniem neizdodas vai ir grūti veikt plānotos uzdevumus nepietiekamu cita mācību priekšmeta zināšanu un prasmju dēḷ. Piemēram, 10. klasē matemātikā skolēni apgūst tematu „Trigonometriskās, logaritmiskās un eksponentfunkcijas". Viens no sasniedzamajiem rezultātiem, kas minēts matemātikas mācību programmas paraugā, ir „lieto IT, aprēḳinot funkciju vērtības, konstruējot funkciju grafikus, pētot funkciju ìpašības un parametru ietekmi uz funkciju grafikiem”. Pētījumā (Priedīte 
2017: 48-51) analizētajā stundā skolēniem bija jāpēta eksponentfunkcijas grafiks - mainot parametru vērtības, jāanalizē, kā mainās funkcijas grafiks un vienādojums, un, izmantojot iegūto informāciju, jāuzraksta vispārīgais vienādojums. Tomēr skolotājs zina, ka, lai arī grafiku veidošanu izklājlapās skolēni ir apguvuši informātikas stundās, šìs prasmes nav pietiekamas, lai izpildītu stundā paredzētos uzdevumus. Viena no iespējām šādā situācijā ir nepieciešamā mācību satura patstāvīga apguve pirms mācību stundas. Sadarbībā ar attiecīgā priekšmeta skolotāju skolēniem tiek piedāvāti materiāli, lai viņi patstāvīgi aktualizētu zināšanas un prasmes, kas apgūtas citā mācību priekšmetā, proti, informātikā. Skolēniem tika piedāvāts mācību video, kurā parādīts un paskaidrots, kā izveidot grafiku. Mājas darbā pirms stundas skolēniem arī pašiem bija jāizveido grafiks. Lai pārliecinātos, ka viņi uzdevumu ir pildījuši, tika lūgts izveidoto grafiku nosūtît skolotājam e-klases vietnē. Tādējādi tika efektīvi izmantots mācību stundas laiks, strādājot ar uzdevumiem, kas palīdz sasniegt matemātikas mācību priekšmeta sasniedzamos rezultātus, nevis kavējot to cita mācību priekšmeta satura aktualizācijai. Ieguvums, šãdi organizējot mācību darbu, ir arī tas, ka, iespējams, skolotājs nav speciālists jautājumā, ko vēlas integrēt, tāpēc viņam ir grūti aktualizēt skolēnu zināšanas savas stundas laikā.

\section{Pētnieciskās darbības prasmju attīstīšana}

Dabaszinātnēs un matemātikā nozīmīga loma ir pētnieciskajai darbībai un skolēna pētniecisko prasmju attīstīšanai. Strādājot ar 11. klasi, tika novērots, ka skolēniem grūtības sagādā laboratorijas darbi fizikā, ir nepieciešams daudz laika un individuāls skolotāja atbalsts, lai veiktu mērijumus, izmantojot fizikas kabinetā pieejamo aprīkojumu - datu uzkrājēju, sensorus, dažādas mērierīces. Līdz ar to mācību stundas laiks netika efektīvi izmantots, jo nepieciešamo zināšanu un prasmju trūkuma dēḷ skolēni stundu laikā nepaspēja veikt pētnieciskā darbu svarīgāko daḷu analizēt iegūtos rezultātus, izdarìt secinājumus. Lai šo problēmu risinātu, tika izmantota apvērstā mācī̌anās. Skolēni pirms stundas noskatījās mācību video par to, kā mērierīces sagatavot darbam, kā pareizi veikt mērījumus, kādi drošības noteikumi jāievēro, lai stundas laikā tās varētu patstāvīgi izmantot. Pētījumā (Priedīte 2017: 54-56) analizētajā stundā tas bija video par ampērmetra un voltmetra izmantošanu. Kā parādijja ieraksti www. eduspace.lv forumā, ko veica skolēni pēc video noskatī̌anās, daḷai skolēnu bija l,oti maza pieredze elektrisko slēgumu veidošanā vai vispār tādas nebija: „Uzzināju ḷoti daudz, jo iepriekš ir minimāli strādāts ar voltmetru.” Tam tā nevajadzētu būt, jo par elektriskajām ķēdēm skolēni ir mācījušies 9. klasē. 


\section{Skolēnu mācību motivācijas veicināšana}

Būtisks mācību procesa uzdevums ir veicināt skolēnu mācību motivāciju. Mājas darbs pirms stundas šajā situācijā tiek izmantots skolēnu ieinteresēšanai. Pētījumā (Priedīte 2017: 57-59) analizētajā stundā skolēni jau iepriekš noskatījās video materiālu par zelta griezumu, bet stundā aprēḳināja cilvēka ķermeņa proporcijas. Video tika izmantots, lai radītu interesi par stundas tematu. Pēc stundas 70 \% skolēnu piekrita, ka video noskatǐšanās radīja interesi par to, kas tiks darīts stundā. Internetā ir pieejams daudz izklaidējošu un izglītojošu video materiālu, ko var izmantot šādam mērḳim. Piemēram, intervijas vai zinātnieku/ mākslinieku/ uzņēmēju uzrunas, kas parāda, kā mācību priekšmeta zināšanas un prasmes var būt noderīgas ārpus mācību stundām. Pētījumā vērtētajā stundā tas bija matemātiķa populārzinātniskas runas fragments par to, kā zelta griezums tiek izmantots dažādos mākslas darbos.

Pētījumā (Priedīte 2017: 39) tika konstatēts, ka apvērstās mācīšanās rezultātā vērojams uzlabojums mācību motivācijā. Skolēnu mācību motivācija tika izvērtēta, izmantojot www.edurio.com anketu, kura tika aizpildīta pirms un pēc piedalīšanās pētījumā. Piemēram, uz jautājumu „Cik bieži Tev ir labi padarīta darba izjūta par stundās paveikto?” pētījuma sākumā pozitīvu atbildi sniedza 36\% skolēnu, bet pētījuma beigās - 53\% skolēnu. Tas varētu būt skaidrojams ar to, ka, izmantojot apvērsto mācīšanos, skolēni jau pirms stundas labāk saprot, ko stundā mācīsies un kas būs jādara. Par to liecina skolēnu izteiktie viedokḷi fokusgrupas diskusijas laikā: „Ar video palīdzību es varēju labi sagatavoties stundai, jo zināju, par ko mēs mācīsimies, un atkārtoju, ko par šo tēmu jau zinu.”, „ Tas ḷauj sagatavoties stundai. Tu atnāc un jau kaut ko zini.”, „Ja godīgi, tad es pat gaidīju tos mājas darbus, man tā patika labāk mācīties nekā parasti.”, „Fizika palika vieglāka, tā mācoties."

\section{Secinājumi un ieteikumi apvērstās mācīšanās īstenošanai}

Analizējot teorētisko literatūru un praktisko pieredzi, var secināt, ka apvērstā mācīšanās fizikā un matemātikā ir veiksmīgi izmantojama, lai:

- aktualizētu iepriekš apgūtās fizikas un matemātikas zināšanas un prasmes,

- īstenojot integrēto mācību stundu, aktualizētu cita mācību priekšmeta zināšanas un prasmes,

- attīstītu skolēnu pētnieciskās darbības prasmes,

- veicinātu skolēnu interesi un motivāciju mācīties.

Visos gadījumos daḷa no stundas ierosināšanas fāzes tiek pārcelta pirms stundas, un skolēni, atnākot uz stundu, jau zina, kāds būs stundas temats un ko viņi mācīsies. 
Šāda mācību organizācijas forma ir ieteicama skolotājiem, kuri parasti izmanto frontālu darbu un uzskata, ka, lai apgūtu zināšanas un prasmes, skolēniem ir nepieciešams skolotāja skaidrojums/ uzdevuma risināšanas paraugs. Izmantojot apvērsto mācišanos, skolēnam joprojām ir pieejams skolotāja stāstijums video materiālos, bet stundās ir laiks strādāt ar augstākas grūtības pakāpes uzdevumiem, attīstìt pašvadības un sadarbības prasmes, bet skolotājam ir laiks sniegt atgriezenisko saiti individuāli vai skolēnu grupām.

Lai apvērstās mācǐšanās dotu vēlamo rezultātu, nepieciešams ņemt vērā šādus ieteikumus:

- izskaidrot skolēniem (jaunākajās klasēs - arī skolēnu vecākiem), kādi ir patstāvīgā mācību darba mērḳi un kāds būs ieguvums, šādi mācoties;

- veidot sistēmu, kas palīdzētu skolēniem plānot laiku un mācīties izvērtēt apgūto, kā arī sniegt atgriezenisko saiti par mājas darba izpildi;

- skaidri definēt, kādi rezultāti skolēnam jāsasniedz ne tikai mācību stundā, bet arī patstāvīgajā darbā, gatavojoties stundai;

- paredzēt vienkāršu risinājumu, kā rīkoties, ja skolēni nav sagatavojušies darbam stundā, piemēram, klasē novietoti divi datori, kurus skolēni var izmantot, lai noskatìtos video;

- video materiālam ir jābūt kvalitatīvam, viegli uztveramam, īsam (5-7 min.). Skolēniem nozīmīgākais ir video saturs, nevis forma. Ērti šādus video ir veidot, izmantojot interaktīvo tāfeli un ekrāna ierakstišanas programmu;

- piedāvāt skolēnu patstāvīgajam darbam ne tikai video materiālus, bet arī papildliteratūru, pašpārbaudes testus, iespēju uzdot jautājumus skolotājam vai citiem skolēniem tiešsaistē;

- izmantot arī internetā pieejamos mācību materiālus, piemēram, www.macibuvideo.lv, https://www.khanacademy.org u. c.;

- veidot patstāvīgā darba materiālus kā mini stundas, ievērojot trīs fāžu stundas modeli. Katra video (vai cita veida materiāla) sākumā iekḷaut ierosināšanas fāzi, kam seko apjēgšanas fāze (kurā tiek izskaidrots temats, demonstrēts piemērs), bet video noslēgumā refleksijas fāzē piedāvāt skolēniem pašpārbaudes uzdevumu;

- izvēelēties sev un skolēniem ērtu tehnisko risinājumu, piemēram, moodle vidi.

Šādas mācību organizācijas formas izmantošanas nozīmīgākie ieguvumi skolēniem ir iespēja sagatavoties darbam stundā un tās laikā būt vairāk pārliecinātiem par savām zināšanām un prasmēm, tādējādi gūstot lielāku gandarījumu par stundā paveikto. Skolēniem ir iespēja gatavoties stundām sev ērtā vietā, laikā un tempā, turklāt interneta vide, ko skolēni izmanto, 
gatavojoties stundām, ir viņiem pierasta un ērti lietojama. Visi šie aspekti veicina skolēnu labizjūtu mācību procesā.

Nozīmīgākais ieguvums skolotājam ir iespēja pirms mācību stundas apkopot jautājumus, kas skolēniem sagādā grūtības, un atbilstoši pielāgot un diferencēt mācību procesu stundā. Skolēni ir ātrāk gatavi darbam stundās, līdz ar to stundas laiku ir iespējams efektīvāk izmantot. Šādi organizējot mācību darbu, samazinās nevienlīdzība skolēnu priekšzināšanās par konkrēto tematu.

Lai arī autores pētījuma rezultāti (Priedīte 2017) norāda uz pozitīviem ieguvumiem, ir nepieciešami turpmāki pētījumi, lai noskaidrotu, kā apvērstā mācīšanās ietekmē skolēnu mācību sasniegumus.

\section{SUMMARY}

Centralized exam results and PISA study results suggest that improvements are necessary in the teaching and learning process in Latvian schools. Pedagogical literature offers different approaches and methods to improve the efficiency of lessons. One of them is flipped learning. The aim of the article "Flipped Learning as a Way to Achieve Various Learning Objectives in Physics and Mathematics Lessons" is to evaluate advantages of this approach for improving learning process in secondary schools. Efficiency of the lesson starts with clearly set goals of the lesson. It is important to understand what kind of learning objectives can be achieved by flipped learning. To investigate this topic an action research was carried out. Participants of the study were two classes of 10th and 11th grade students (58 students) and 2 teachers. Flipped learning was used for the period of four months. During the study lesson plans in physics and mathematics were developed and piloted. The following research methods were used for data collection and analyses: lesson observation and analyses, students' questionnaires, analyses of teachers' reflections. A summary of the research results allows to conclude that flipped learning can be used for 1) prior knowledge actualization; 2) implementation of the integrated lesson;

3) development of research skills; 4) encouraging students' motivation. The article offers recommendations for implementation of the flipped learning approach.

\section{LITERATŪRAS SARAKSTS}

Bergmann 2013 Bergmann, J. (2013) Key Questions You Should Ask Before You Flip Your Class. Pieejams: http://flglobal.org/key-questions-you-shouldask-before-you-flip- your-class/ [Skatîts: 06.01.2017.] 
Bergmann, Sams Bergmann, J. \& Sams, A (2012). Flip Your Classroom: Reach Every 2012 Student in Every Class Every Day. International Society for Technology in Education. Pieejams: https://escolaecofeliz.files.wordpress. com/2015/12/flip-your- classroom.pdf [Skatīts: 30.12.2016.]

Bhagat, Chang, Bhagat, K. K., Chang, C. N., \& Chang, C. Y. (2016) The Impact of the Chang $2016 \quad$ Flipped Classroom on Mathematics Concept Learning in High School. Educational Technology \& Society, 19 (3), pp. 134-142. Pieejams: https://www.researchgate.net/profile/Kaushal_Bhagat2/publication/286047548_The_Impact_of_the_Flipped_Classroom_on_ Mathematics_Concept_Learning_in_High_sch ool/links/5720a8a308 aed056fa277033.pdf [Skatîts: 12.08.2018.]

Creative Clasroom Creative Classroom Lab (2015) Innovative Teaching and Learning Lab 2015

Čakāne et al. with Tablets. Brussels: European Schoolnet, pp. 6-7.

2016

Čakāne, L. \&France, I. \& Kālis, M. \& Ančupāns, A. (2016). Matemātikas centralizētais eksāmens 2015./2016. m. g.; skolēnu rezultātu un snieguma analize. Metodiskais materiāls. Pieejams: http://visc.gov.lv/vispizglitiba/eksameni/metmat.shtml [Skatīts: 28.12.2016.]

France et al. 2015 France, I., Namsone, D. \& Čakāne, L. (2015) What Research Shows About Mathematics Teachers' Learning Needs: Experience from Latvia. Society, Integration, Education. Proceedings of the International Scientific Conference 05/2015; vol. 2. Rēzekne: Rēzeknes Augstskola, 45.-55. lpp. Pieejams: http://journals.ru.lv/ index.php/SIE/article/view/457/44 [Skatîts: 15.01.2017.]

Geske et al. 2016 Geske, A. \& Grīnfelds, A. \& Kangro, A. \& Kiselova R. (2016). Latvija OECD Starptautiskajā skolēnu novērtēšanas programmā 2015 - pirmie rezultāti un secinājumi. Rīga: Latvijas Universitāte.

Hao, Lee 2016 Hao, Y. \& Lee, K. (2016) Teaching in Flipped Classrooms: Exploring Pre-service Teachers' concerns. Computers in Human Behaviour, 57, pp. 250-260. Pieejams: http://dx.doi.org/10.1016/j. chb.2015.12.022 [Skatîts: 10.08.2018.]

Lai, Hwang 2016 Lai, C. \& Hwang G. (2016) A Self-regulated Flipped Classroom Approach to Improving Students' Learning Performance in a Mathematics Course. Computers \& Education, 100, pp. 126-140. Pieejams: http://dx.doi.org/10.1016/j.compedu.2016.05.006 [Skatìts: 11.08.2018.]

Mok 2014 Mok, H. N. (2014). Teaching Tip: The Flipped Classroom. Journal of Information Systems Education, 25 (1), pp. 7-11 Pieejams: https:// pdfs.semanticscholar.org/326f/0993c470c1c4359846d00ff8b370ae 738c09.pdf [Skatīts: 12.08.2018.]

Priedīte 2017 Priedīte, A. (2017) Apvērstās mācišanās pieeja fizikas un matemātikas mācỉbu procesa pilnveidei vidusskolā. Mağistra darbs. Latvija: Rīga.

Toivola, Toivola, M. \& Silfverberg H. (2014) Flipped Learning Silfverberg 2014 Approach in Mathematics Teaching - A Theoretical Point of View. Annual Symposium of the Finnish Mathematics and Science Education Research Association. [Online] Pieejams: http://www. academia.edu/17424961/FLIPPED_LEARNING_APPROACH_IN_ MATHEMATICS_TEACHING_A_THEORETICAL_POINT_OF_VIEW [Skatīts: 22.04.2017.] 